V Seminário Anual Científico e Tecnológico | Bio-Manguinhos

\title{
V 08 - Avaliação de alternativas para a abertura de ovos spf no DEVIR
}

Cíntia Cardoso da Costa1*; Carla Mônica Pinheiro1; Claudia Maria Lopes Leibel1; Wania Renata dos Santos1.

1Bio-Manguinhos / Fiocruz.

\section{Introdução:}

A produção em Bio-Manguinhos do Insumo Farmacêutico Ativo (IFA) da vacina febre amarela atenuada e dos IFA de sarampo e caxumba, componentes da vacina TVV (contra sarampo, caxumba e rubéola) envolve a multiplicação viral em plataforma de embriões de galinha SPF (livres de agentes patogênicos) ou derivados (fibroblastos).

Os métodos utilizados atualmente para a abertura das cascas dos ovos e coleta dos embriões apresentam um potencial de geração de partículas totais no monitoramento ambiental o que não é desejável em ambientes classificados.

\section{Objetivo:}

Esse trabalho propõe a busca por novas tecnologias para melhoria no processo de abertura de ovos SPF utilizados na produção do IFA de febre amarela e dos IFA de sarampo e caxumba, componentes da vacina TVV.

\section{Metodologia:}

Foram testados cortadores a laser e cortadores pneumáticos no processo de abertura de ovos.

\section{Resultado:}

O protótipo de cortador a laser demonstrou um corte preciso das cascas dos ovos. Entretanto, o tempo necessário para abertura de cada ovo foi inicialmente alto e após aperfeiçoamento pela empresa obteve-se um tempo médio de $4 \mathrm{~s}$ para cada ovo, mas com aumento no custo para aquisição do equipamento. Houve também evidente geração de particulado durante o processo e mesmo com o posicionamento do exaustor próximo aos ovos, o monitoramento de partículas mostrou valores muito acima dos limites especificados para áreas de grau A. Os cortadores pneumáticos permitiram agilidade compatível ao processo de abertura de ovos para produção dos IFA de caxumba e sarampo, além do custo mais acessível do equipamento. Os níveis de partículas totais alcançados nesses testes foram satisfatórios para áreas de grau A. 


\section{Conclusão:}

O cortador pneumático apresentou os melhores resultados, sendo mais leve e prático, conferindo também, mais flexibilidade e agilidade no seu manuseio o que otimizou o tempo de processo de abertura de ovos. O processo foi visivelmente mais limpo (sem extravasamento da clara), percebido também através da contagem de partículas totais. Houve a manutenção da integridade da membrana alantoide, levando a um maior rendimento dos embriões coletados. Além disso a logística envolvendo os materiais utilizados nos processos foi ainda reduzida com o uso deste equipamento.

Palavras-chave: Processos de produção de IFA; febre amarela, sarampo, caxumbra; Ovos spf. 